\section{Japanese originality}

\section{Can Japan shake off the slur of imitivity without} reforming the universities?

THE Japanese are once again worrying about their supposed lack of creativity (see p.173), this time not simply because uncharitable Westerners have been pointing out that the Japanese did not actually invent the video-cassette recorder. Rather, an analysis of publications in international science journals (albeit a tiny sample) suggests that, in basic research, an enormous gulf still separates Japan from the United States. Although the white paper from the Science and Technology Agency charts quite a few differences between Japan and other countries that may help to account for Japan's poor performance, the uncomfortable feeling persists that Japan is not really doing as well as it should. Japan, after all, is spending on basic research 35 per cent of what is spent in the United States, but its people's output of scientific papers is an order of magnitude less.

Many factors may be to blame, of which one must be the lack of a tradition of scientific excellence. Language is also a severe handicap; even a Japanese who has lived abroad will be lucky if he can read scientific English a quarter as fast as a native speaker. Even so, in Japan as elsewhere, success is likely to be a function of the product of talent and resources; if clever people have the right facilities, they will do good work. But in Japan, resources may not effectively reach the talent that there is. The Ministry of Education, Culture and Science (MESC, the principal support agency for basic research) distributes its research grants with the help of some 800 advisers in the numerous committees of its Science Council. The advisers are, by and large, the grand old men of Japanese science, selected as the most esteemed representatives of the various academic societies that advise the ministry. Although many have done great things in their day, not all are on top of the latest developments. Yet a well-cultivated connection with a figure on the relevant grants committee may serve an applicant as well (or perhaps better) as the quality of the grant proposal itself. The system of forming close relationships between junior and senior figures, and the patronage it produces is, however, thoroughly Japanese: suggestions that it should simply be replaced by a more open system of assessment is received with much the same horror as the suggestion that hamburgers should replace raw fish as the national dish.

The real losers are those talented people at lesser known universities who have not been able to cultivate powerful sponsors in Tokyo. The unknown are not altogether forgotten, however. There is a countervailing tradition of Japanese democracy that nobody should be entirely ignored. The result is that a huge number of small grants (less than US $\$ 10,000$ ) are given out to all and sundry, which leaves very little for the really big grants that could give a group international status. Special promotion grants, worth on the average about $\$ 350,000$ a year and specially aimed at research "likely to produce outstanding results", are given to only six groups a year. But, to be fair, these grants are still quite new. They show that MESC is making some first efforts to concentrate its resources where they can be most effective. The ministry is also taking some steps to give freedom and money to exceptional young people. This year,postdoctoral fellowships just 200 of them - will be available for two-year periods, and there are hopes that the numbers can be increased.

These developments do not, however, satisfy the other ministries and industry, frustrated by the slow pace of change at the universities. The Science and Technology Agency is pumping growing sums of money into its own research institutes, some of which carry out basic research in fields such as molecular biology, lasers and heavy-ion physics which is no different from that at universities. And industry, disappointed at the unwillingness of the universities to take on contract work (where MESC is also beginning to make reforms), is setting up its own academic research institutes, raising the prospect that there may eventually be several parallel organizations for basic research - with no major changes at the universities. The Science and Technology
Agency is too polite to suggest reforms to the Ministry of Education, but the trends noted in the report, and the slowness of change in the Ministry of Education, should be of serious concern to the universities.

\section{Attorneys' comeuppance}

\section{A judge has questioned lawyers' fees, perhaps making it unprofitable for them to ape vultures.}

THE ambulance-chasing lawyer is not unique to the United States, but the American legal profession consistently shows a special genius in finding profit in the misfortune of others. Last month's tragedy in Bhopal brought this home with the sight of squadrons of US lawyers descending upon the worst-ever industrial accident. That the Bhopal victims have a cause of action is undeniable. That they need American lawyers, armed with contingency-free contracts, to secure justice is less certain. And it is less certain still that ambulance-chasing lawyers could even exist if the US legal system were in proper shape.

The United States has seen an explosion of personal injury claims in recent years, some worthy and some not. The social cost is enormous - vast sums of money are spent on legal research, the preparation of tons of documents and sparring over technicalities. A rational society would institute compensation schemes, but when a number of US states attempted to institute no-fault automobile insurance, the greatest opposition came from those who have profited most from the status quo - the lawyers.

Sceptics need only to look in the classified telephone directory of any American city to taste the flavour of legal entrepreneurship. Full-page advertisements are common. "ACCIDENT CLAIMS? SEE A LAWYER" reads one. Another provides a sort of shopping list of possible grounds for a lawsuit: medical malpractice, airplane crashes, defective products, dangerous premises and "other accidents and serious injury cases". One entrepreneur offers free initial consultation either "in your home or in your hospital room".

The American tradition in personal injury cases is that attorneys' fees are negotiated between the client and his attorney; it is rarely possible to collect directly from the losing defendant. The result is that the courts have nothing to say about fees. The exceptions are class actions, the aim of which is the creation of a fund to compensate not just an attorney's clients but anybody else who has suffered the same injury. Under federal court rules, it is up to the court to determine fees in such cases, charging them out of the fund or, in some instances, against the defendant. Last week, a federal court in New York exercised this right with a vengeance - this time against the plaintiffs' attorneys. It sent a clear message that the day of the windfall may be over.

The case was the Agent Orange class action, the suit brought by thousands of Vietnam veterans who claimed serious and persisting health damage from their wartime exposure to defoliants. The chemical companies named as defendants, while not admitting liability, had agreed to settle for $\$ 180$ million. In other class actions, courts have been quite generous to the winning attorneys. Not only have they received hourly fees and expenses, they have also often been awarded "multipliers" of hourly fees to compensate them for the risks of taking on the case. On one occasion, a court awarded four times the usual attorneys' fees. Last week, however, the court did something different. It thoroughly dissected the fee claims of the 100 attorneys involved, rewarding those it felt had made an exceptional effort on behalf of claimants (but in no case awarding fees of more than $\$ 150$ per hand and a multiplier of 1.5), and throwing out vast chunks of the expenses submitted by others.

The lawyers involved are crying foul. One said "it's going to drive competent counsel out of this area". Not everybody will consider that a loss. On the contrary, it may be a modest first step towards driving all counsel out of personal injury litigation, which process will be complete only when statutes providing for administrative compensation of injuries replaces the current relics of common law. 